Research paper

\title{
Structural meta-analysis of regular human insulin in pharmaceutical formulations
}

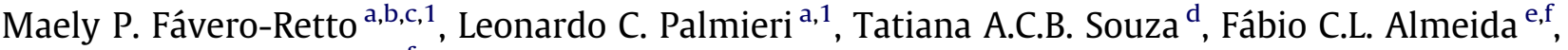 \\ Luís Mauricio T.R. Lima ${ }^{a, f, g, *}$ \\ a School of Pharmacy, Federal University of Rio de Janeiro - UFRJ, Rio de Janeiro, Brazil \\ ${ }^{\mathrm{b}}$ Brazilian National Cancer Institute (INCA), Rio de Janeiro, Brazil \\ ${ }^{\mathrm{c}}$ Brazilian National Institute of Traumatology and Orthopedics (INTO), Rio de Janeiro, Brazil \\ ${ }^{\mathrm{d}}$ Brazilian Synchrotron Light Laboratory (LNLS-CNPEM), Campinas, Brazil \\ ${ }^{\mathrm{e}}$ National Center for Nuclear Magnetic Resonance - CNRMN, Institute for Medical Biochemistry, Federal University of Rio de Janeiro - UFRJ, Rio de Janeiro, Brazil \\ ${ }^{\mathrm{f}}$ National Institute of Science and Technology for Structural Biology and Bioimaging (INBEB-INCT), Federal University of Rio de Janeiro, Rio de Janeiro, Brazil \\ ${ }^{\mathrm{g}}$ Laboratory for Structural Biology (DIMAV), Brazilian National Institute of Metrology, Quality and Technology - INMETRO, Rio de Janeiro, Brazil
}

\section{A R T I C L E I N F O}

\section{Article history:}

Received 29 November 2012

Accepted in revised form 6 May 2013

Available online 18 May 2013

\section{Keywords:}

Human insulin

Crystallography

Nuclear magnetic resonance

Mass spectra

Small-angle X-ray scattering

Biosimilar

Meta-analysis

\begin{abstract}
A B S T R A C T
We have studied regular acting, wild-type human insulin at potency of $100 \mathrm{U} / \mathrm{mL}$ from four different pharmaceutical products directly from their final finished formulation by the combined use of mass spectrometry (MS), dynamic light scattering (DLS), small-angle X-ray scattering (SAXS), nuclear magnetic resonance (NMR), and single-crystal protein crystallography (PX). All products showed similar oligomeric assembly in solution as judged by DLS and SAXS measurements. The NMR spectra were compatible with well folded proteins, showing close conformational identity for the human insulin in the four products. Crystallographic assays conducted with the final formulated products resulted in all insulin crystals belonging to the R3 space group with two a dimer in the asymmetric unit, both with the B-chain in the $\mathrm{T}$ configuration. Meta-analysis of the 24 crystal structures solved from the four distinct insulin products revealed close similarity between them regardless of variables such as biological origin, product batch, country origin of the product, and analytical approach, revealing a low conformational variability for the converging insulin structural ensemble. We propose the use of MS, SAXS, NMR fingerprint, and PX as a precise chemical and structural proof of folding identity of regular insulin in the final, formulated product.
\end{abstract}

(c) 2013 Elsevier B.V. All rights reserved.

\section{Introduction}

The onset of diabetes mellitus (DM) and loss of control of metabolism affects a large part of the world population [1,2]. Large effort has been made for the development of new therapeutics for the control of DM as well as in the search for its cure [3-5,5-11].

However, therapeutic reposition of pancreatic hormones - such as insulin and amylin and their analogs - has not been replaced and still remains an important therapy [12-14] which motivates the worldwide development and revision of process for the

Abbreviations: NMR, nuclear magnetic resonance; SAXS, small-angle X-ray scattering; MALDI-TOF, matrix-assisted laser desorption/ionization - time-of-flight; hINS, human insulin.

* Corresponding author. School of Pharmacy, Federal University of Rio de Janeiro - UFRJ, CCS, Bss34, Ilha do Fundão, 21941-590 Rio de Janeiro, RJ, Brazil. Tel./fax: +55 2125626639.

E-mail address: LML@UFRJ.BR (L.M.T.R. Lima).

1 These authors contributed equally to this work. production of insulin, new insulin products, analogs, and delivery systems [3,15-20] in addition to the large portfolio of insulin products and analogs currently available from different brands.

Along with the inherent difficulties of developing and producing a biological products for therapeutic use, characterization of the final product is also challenging and demands a continuous revision process of analytical methods and quality requirements applied for pharmaceutical ingredients, finished and in-process products.

Protein therapeutics are a class of products which have a complex three dimensional structure in solution whose integrity determines the biological activity, clinical efficacy, and safety. Thus, it is highly desirable that products from this class meet well-defined requirements for structural integrity. Proteolytic footprint has long been the method of choice, generating a peptide mapping which indirectly provides evidences for solution structural arrangement [21]. Previous work have shown that slight changes in excipient used in insulin formulation can result in redistribution of 
oligomeric forms [22,23]. However, besides its high analytical precision and sensitivity, this approach is not sufficient to provide the exact three-dimensional structure of these biological entities.

Still remains the question whether the assessment of structural information could be satisfactorily performed in the final finished biological product, providing chemical information about the molecular integrity and the detailed structural information about the exact three-dimensional structure of these biological entities in its final formulations. To address this issue, we have conducted an extensive structural and spectroscopic characterization of regular-acting, wild-type human insulin formulations at same potency of $100 \mathrm{U} / \mathrm{mL}$ from four distinct brands.

Insulin is a protein hormone used worldwide in the treatment of diabetes. Its active form is comprised of polypeptide chains $A$ and $\mathrm{B}$, linked by three disulfide bonds. Insulin crystals have been investigated for decades [24-26], and the insulin high resolution structure has long been known from varying crystallographic techniques such as single crystals [27] and microcrystalline powder [28] diffraction. NMR has also been used in the structural characterization of insulin in its varying oligomeric and conformational states, such as monomers [29], $T_{6}, T_{3} R_{3}^{f}$ [30] and $R_{6}$ hexamer [31] and in comparative studies with diverse mutants [32-35] and also in diverse solution composition [32,34,36]. The choice of the products used in the present study was based on the fact that they are pharmaceutically available for therapeutic use and are produced by four dissimilar methods such as the heterologous recombinant production (in Escherichia coli, Saccharomyces cerevisae or Pichia pastoris) and by the semi-synthetic approach (by the modification of the aminoacid $\mathrm{Thr}^{\mathrm{B} 30}$ in porcine insulin), also varying in the excipient composition.

\section{Experimental}

\subsection{Chemicals}

Human insulin formulations at $100 \mathrm{U} / \mathrm{mL}$ were acquired direct from pharmaceutical drug stores and kept under refrigeration at $4{ }^{\circ} \mathrm{C}$ until use. We used in this work several insulin batches, as depicted in Table 1 . We did not detect aggregates according to the DLS and SAXS measurements (Table 3 and Fig. 1).

We have also used the insulin analogs Asp $^{28 B}$ (Aspart insulin, NovoRapid Penfill Aspart Insulin lot \# XS62590) [37] and Lys28B Pro29B (LisPro insulin, Humalog Lispro Insulin lot \# a696780) [38] for the evaluation of the selectivity of the crystallization conditions (see below). All other reagents were of analytical grade.

\subsection{Mass spectra using MALDI-TOF}

Insulin formulations were diluted 10 times with acetonitrile/ water 50:50 (v/v) containing $0.1 \%$ trifluoroacetic acid (TFA) v/v. Alfa-cyano-4-hydroxycinnamic acid (CHCA; $10 \mathrm{mg} / \mathrm{mL}$ in $\mathrm{CHCN}_{3}$, $0.1 \%$ TFA in water; $2: 1, v / v$ ) was used as the matrix agent in a $1: 1$ mixture with the insulin solution in $\mathrm{CHCN}_{3} .1 \mu \mathrm{L}$ of $\mathrm{CHCA}-$ insulin mixture was applied to the sample plate and air-dried at room temperature. The MALDI-TOF mass spectra were recorded using an Applied Biosystems Voyager instrument from Proteomics Facility at IBqM-UFRJ, calibrated using external standards at each 2 sample measurements.

\subsection{Dynamic light scattering}

Particle size distribution of the human insulin formulations was evaluated $(n=3)$ at $25^{\circ} \mathrm{C}$ by dynamic light scattering in a DynaPro NanoStar (Wyatt Technology, USA) previously calibrated according to manufacturer. The relative percentage polydispersity (\% PD) was
Table 1

Summary of human regular insulin formulation used in this study.

\begin{tabular}{|c|c|c|c|c|}
\hline $\begin{array}{l}\text { Product/ } \\
\text { composition }^{\mathrm{a}}\end{array}$ & Company & $\begin{array}{l}\text { Batch } \\
\text { number }\end{array}$ & $\begin{array}{l}\text { Country of } \\
\text { manufacturing }\end{array}$ & $\begin{array}{l}\text { Country of } \\
\text { acquisition }\end{array}$ \\
\hline $\begin{array}{l}\text { Humulin }{ }^{\circledR} \text { R Human } \\
\text { insulin (rDNA } \\
\text { origin; E. coli) } \\
100 \text { units/mL, } \\
\text { glycerol } 16 \mathrm{mg} / \\
\text { mL, metacresol } \\
2.5 \mathrm{mg} / \mathrm{mL} \text {, } \\
\text { endogenous zinc } \\
\text { (0.015 mg Zn), pH } \\
7.0-7.8\end{array}$ & Eli Lilly & $\begin{array}{l}\text { A405936 } \\
\text { A560347 } \\
\text { A505073 }\end{array}$ & $\begin{array}{l}\text { Mexico } \\
\text { Mexico } \\
\text { EUA }\end{array}$ & $\begin{array}{l}\text { Brazil } \\
\text { Mexico } \\
\text { Argentina }\end{array}$ \\
\hline $\begin{array}{l}\text { Novolin }{ }^{\circledR} \text { R Human } \\
\text { insulin (rDNA } \\
\text { origin; } S \text {. } \\
\text { cerevisiae) } 100 \mathrm{U} / \\
\text { mL, glycerol } \\
16 \mathrm{mg} / \mathrm{mL}, \\
\text { metacresol } 3 \mathrm{mg} / \\
\text { mL, endogenous } \\
\text { zinc }(0.007 \mathrm{mg} \text { ), } \\
\text { pH } 7.4\end{array}$ & $\begin{array}{l}\text { Novo } \\
\text { Nordisk }\end{array}$ & $\begin{array}{l}\text { XS69303 } \\
\text { TS62987 } \\
\text { TS62953 }\end{array}$ & $\begin{array}{l}\text { Denmark } \\
\text { Denmark } \\
\text { Denmark }\end{array}$ & $\begin{array}{l}\text { Brazil } \\
\text { Mexico } \\
\text { Argentina }\end{array}$ \\
\hline $\begin{array}{l}\text { Insunorm }{ }^{\circledR} \text { R Human } \\
\text { insulin (rDNA } \\
\text { origin; P. pastoris) } \\
100 \mathrm{U} / \mathrm{mL} \text {, } \\
\text { endogenous zinc, } \\
\text { glycerol, } \\
\text { metacresol }\end{array}$ & Cellofarm & I550005 & India & Brazil \\
\hline $\begin{array}{l}\text { Betalin }{ }^{\circledR} \text { H Human } \\
\text { insulin (semi- } \\
\text { synthetic) } 100 \mathrm{U} / \\
\text { mL, endogenous } \\
\text { zinc, glycerol, } \\
\text { phenol }\end{array}$ & Beta Lab & $\begin{array}{l}310996- \\
1\end{array}$ & Argentina & Argentina \\
\hline
\end{tabular}

evaluated from the number average intensity, representing the percentage of the peak size half width divided by the mean peak size.

\subsection{Small angle X-ray scattering}

SAXS experiments were carried out at the D11-SAS1 beam line [39] on the LNLS. SAXS data were collected directly from the regular human insulin formulations using a two-dimensional detector (MarCCD; MarResearch, USA) at wavelength $1.488 \AA$ with a sample-detector distance providing a $q$-range from $0.02 \AA^{-1}$ to $0.25 \AA^{-1}$, where $q$ is the modulus of the scattering vector (calculated according to $q=(4 \pi / \lambda) \sin \theta$, where $\lambda$ is the wavelength used and $2 \theta$ is the scattering angle). The scattering curves of the protein solutions and buffers were collected in several successive frames of $500 \mathrm{~s}$ each to monitor for radiation-induced protein oxidation. The data reduction routine included normalization of the one-dimensional scattered data to the intensity of the transmitted incident beam, correction for the detector response, incident beam intensity, sample absorption, and blank subtraction using scattering from water.

A Guinier analysis of solution scattering [40] was applied to evaluate the monodispersity of each specimen and to determine the radius of gyration $(\mathrm{Rg})$ of Insulin $\mathrm{R}$ in solution. The $\mathrm{Rg}$ and the scattered intensity, $I(q)$, were inferred, respectively, from the slope and the intercept of the linear fit of $\ln [I(q)]$ versus $q^{2}$ in the $q$-range $q * \operatorname{Rg}<1.3$ [40]. The same parameter was also obtained from the data fit of the merged curve by the indirect Fourier transform program Gnom [41], also evaluating the distance-distribution 

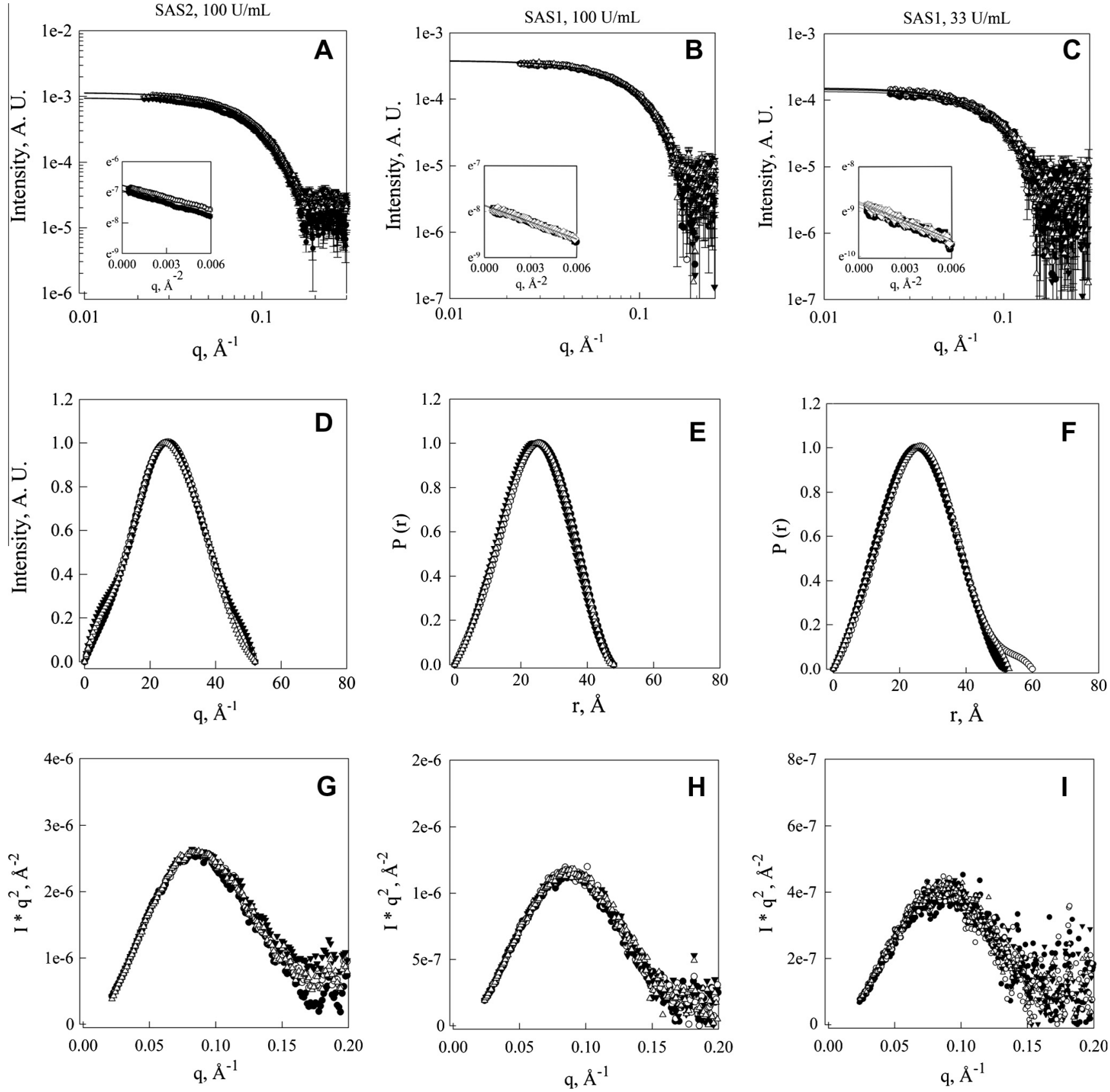

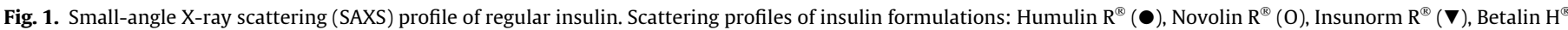

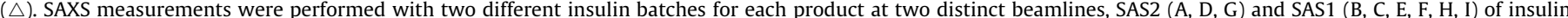

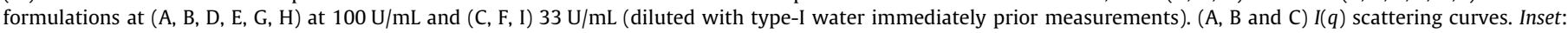

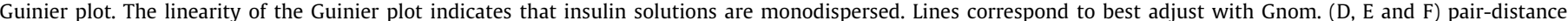

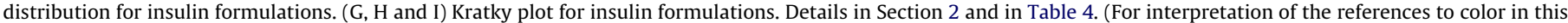
figure legend, the reader is referred to the web version of this article.)

function, $P(r)$, of Insulin R. The maximum dimension, $D_{\max }$, was estimated from the distance distribution function $P(r)$, with the limiting distance $r$ where $P(r)$ first converges down to zero.

\subsection{Protein crystallography}

Crystals of the human insulin were obtained by hanging drop at temperature varying from $18{ }^{\circ} \mathrm{C}$ to $25^{\circ} \mathrm{C}$ as specified (Table S1), by direct mixing $2 \mu \mathrm{L}$ of the insulin formulations with $2 \mu \mathrm{L}$ of well solution and equilibrating against $500 \mu \mathrm{L}$ of well solution. Crystals of approximately $50-100 \mu \mathrm{m}$ grew in about 2 days. The crystals were quickly soaked in well solution supplemented with varying glycerol concentrations and subjected to X-ray diffraction and data collection under nitrogen stream at $100 \mathrm{~K}$ (with previous flashcooling in liquid nitrogen or by direct flash-cooling with the nitrogen stream, as depicted in Table S1) in varying setups, as follow:

- the MX1 synchrotron beamline [42] from the National Synchrotron Light Laboratory, Campinas, Brazil (LNLS-CNPEM), recorded on a MARCCD165;

- the MX2 synchrotron beamline [43] from the National Synchrotron Light Laboratory, Campinas, Brazil (LNLS-CNPEM), with the diffraction intensities recorded using a MarMosaic 225 detector (MAR Research GmbH, Norderstedt, Germany); 
Table 4

Small-angle X-ray scattering analysis of insulin products.

\begin{tabular}{|c|c|c|c|c|}
\hline & Humulin ${ }^{\circledR} \mathrm{R}$ & Novolin ${ }^{\circledR} \mathrm{R}$ & Insunorm ${ }^{\circledR} \mathrm{R}$ & Betalin ${ }^{\circledR} \mathrm{H}$ \\
\hline \multicolumn{5}{|c|}{ SAS1 $(100 \mathrm{U} / \mathrm{mL})$} \\
\hline Guinier & $\begin{array}{l}18.8 \\
\left(r^{2}=0.971\right)\end{array}$ & $\begin{array}{l}18.9 \\
\left(r^{2}=0.976\right)\end{array}$ & $\begin{array}{l}19.0 \\
\left(r^{2}=0.980\right)\end{array}$ & $\begin{array}{l}19.0 \\
\left(r^{2}=0.978\right)\end{array}$ \\
\hline$P(r)$ & $18.6 \pm 0.03$ & $18.5 \pm 0.03$ & $18.8 \pm 0.04$ & $18.5 \pm 0.04$ \\
\hline$D_{\max }(\AA)$ & $48 \pm 2$ & $48 \pm 2$ & $50 \pm 2$ & $48 \pm 2$ \\
\hline \multicolumn{5}{|c|}{$\begin{array}{l}\text { SAS1 }(33 \mathrm{U} / \mathrm{mL}) \\
\operatorname{Rg}(\AA)\end{array}$} \\
\hline Guinier & $\begin{array}{l}19.0 \\
\left(r^{2}=0.928\right)\end{array}$ & $\begin{array}{l}20.1 \\
\left(r^{2}=0.952\right)\end{array}$ & $\begin{array}{l}19.1 \\
\left(r^{2}=0.929\right)\end{array}$ & $\begin{array}{l}20.1 \\
\left(r^{2}=0.946\right)\end{array}$ \\
\hline$P(r)$ & $19.2 \pm 0.07$ & $20.2 \pm 0.07$ & $19.3 \pm 0.09$ & $19.7 \pm 0.06$ \\
\hline$D_{\max }(\AA)$ & $52 \pm 2$ & $60 \pm 2$ & $52 \pm 2$ & $53 \pm 2$ \\
\hline \multicolumn{5}{|c|}{$\begin{array}{l}\text { SAS2 }(100 \mathrm{U} / \mathrm{mL}) \\
\operatorname{Rg}(\AA)\end{array}$} \\
\hline Guinier & $\begin{array}{l}20.4 \\
\left(r^{2}=0.998\right)\end{array}$ & $\begin{array}{l}19.9 \\
\left(r^{2}=0.998\right)\end{array}$ & $\begin{array}{l}20.1 \\
\left(r^{2}=0.998\right)\end{array}$ & $\begin{array}{l}19.8 \\
\left(r^{2}=0.997\right)\end{array}$ \\
\hline$P(r)$ & $19.6 \pm 0.03$ & $19.45 \pm 0.02$ & $19.63 \pm 0.03$ & $19.3 \pm 0.03$ \\
\hline$D_{\max }(\AA)$ & $52 \pm 2$ & $52 \pm 2$ & $52 \pm 2$ & $52 \pm 2$ \\
\hline
\end{tabular}

- a home source, using $\mathrm{Cu} \mathrm{K} \alpha$ radiation generated by a Rigaku UltraX 18 rotating anode operated at $50 \mathrm{kV}$ and $90 \mathrm{~mA}$, equipped with Osmic confocal Max-Flux optics and recorded on a MAR 345dtb image plate;

- a home source, using $\mathrm{Cu} \mathrm{K} \alpha$ radiation generated by a NOVA source installed in a SuperNova diffractometer (Agilent) operated at $50 \mathrm{kV}$ and $0.8 \mathrm{~mA}$ and recorded on a Titan (Agilent) area detector.

The images were indexed and processed with Mosflm [44] or CrysAlisPro [45] and scaled with Scala [46]. The complex was solved by molecular replacement using MolRep [47] or Phaser [48] and human insulin crystal structure (PDB entry: 3I3Z) as search model, resulting in a clear solution for a dimer in the asymmetric unit. The structure was further refined using Refmac [49]. Real space refinement was conducted by visual inspection of both the map and model with Coot [50], which was also used for the addition of water molecules and zinc ions. A summary of crystal parameters and data collection and refinement statistics are presented in Table 4. Structural validation of the model performed with PROCKECK [51] showed that all main-chain dihedral angles were in the allowed regions. All residues were found in favorable Ramachandran regions. A detailed report of structure statistics can be found in Table S1. All figures were generated with PyMOL [52]. Global pairwise alignment of the insulin structures was performed using Pro-SMART [53] considering the two monomers in the asymmetric unit as a single structural unit, to achieve the global RMSD corresponding to the superposition of two pairs of monomers. The atomic coordinates have been deposited with the Protein Data Bank and have been assigned the codes as depicted in Table S1.

Table 2

Mass spectrometry analysis of human insulin.

\begin{tabular}{lll}
\hline Formulation/brand & Batch number & $m / z$ \\
\hline Humulin $^{\circledR} \mathrm{R}$ & A405936 & 5809.92 \\
& A560347 & 5808.89 \\
& A505073 & 5809.07 \\
Novolin $^{\circledR} \mathrm{R}$ & XS69303 & 5809.93 \\
& TS62987 & 5808.94 \\
Insunorm $^{\circledR} \mathrm{R}$ & $\mathrm{I} 550005$ & 5809.92 \\
Betalin $^{\circledR} \mathrm{H}$ & $310996-1$ & 5809.07 \\
\hline
\end{tabular}

Table 3

Dynamic light scattering analysis of human insulin formulations.

\begin{tabular}{lll}
\hline & Hydrodynamic radius $(\mathrm{Rh})(\AA)$ & Polydispersity $(\mathrm{Pd})(\%)$ \\
\hline Humulin $^{\circledR} \mathrm{R}$ & $17.0 \pm 0.3$ & $3.8 \pm 0.9$ \\
Novolin $^{\circledR} \mathrm{R}$ & $20.2 \pm 0.4$ & $4.5 \pm 0.4$ \\
Insunorm $^{\circledR} \mathrm{R}$ & $19.6 \pm 1.4$ & $4.4 \pm 0.3$ \\
Betalin $^{\circledR} \mathrm{H}$ & $18.9 \pm 2.5$ & $3.3 \pm 1.4$ \\
\hline
\end{tabular}

\subsection{Nuclear magnetic resonance}

The NMR measurements were performed with the following human insulin products and their respective batch number: Humulin ${ }^{\circledR}$ R (Eli Lilly; Brazil) lot \#A562606; Novolin ${ }^{\circledR}$ R (Novo Nordisk, Brazil) lot \#TS62953; Insunorm ${ }^{\circledR} \mathrm{R}$ (Cellofarm, Brazil) lot \#I550005; Betalin ${ }^{\circledR}$ H Corriente Semisintetica lot \#44713. Samples was prepared by adding $\mathrm{D}_{2} \mathrm{O}(\sim 10 \% \mathrm{v} / \mathrm{v}$ final concentration) directly to each insulin formulation. NMR experiments were performed on a $600 \mathrm{MHz}$ Bruker Avance III spectrometer equipped with a cryogenic probe (from the CNRMN-UFRJ) using pulse programs implemented in Bruker Top Spin pack and on a Varian $500 \mathrm{MHz}$ INOVA also equipped with a cryogenic probe (from the LNBio-CNPEN) using pulse programs implemented in VNMRJ $\mathrm{v}$ 2.1. Temperature of $25^{\circ} \mathrm{C}$ was used for all experiments. For 2D ${ }^{13} \mathrm{C}$-HSQC spectra (for Bruker pulse sequence hsqcetgp, avanceversion 07/04/04 or for Varian pulse sequence gChsqc), we used natural abundant ${ }^{13} \mathrm{C}$ signal of samples and 1024 transients in ${ }^{1} \mathrm{H}$ dimension and 128 transients in ${ }^{13} \mathrm{C}$ dimension. Data from Bruker were processed with Bruker Top Spin pack or data from Varian were processed with nmrPipe suite [54] and analyzed with Computer Aided Resonance Assignment (CARA [55]).

\section{Results}

\subsection{Molecular weight determination by mass spectrometry}

We have conducted an initial characterization of the four regular insulin products by mass spectrometry. The MALDI-TOF analysis showed a peak with $\mathrm{m} / \mathrm{z}$ of 5809 for all insulin products (Table 2). This result is in agreement with the expected molecular mass for wild-type, human insulin and thus confirms the chemical identity and integrity of the insulin product in the formulation tested, regardless of the manufacturing process.

\subsection{Evaluation of the oligomeric organization by dynamic light scattering}

We have evaluated the oligomeric properties of the regular insulin products in the pharmaceutical formulation by dynamic light scattering (DLS). We have observed similar particle behavior in solution for the insulin from the insulin formulation from four distinct products, as evidenced by the close hydrodynamic radius within error, ranging from 18 to $20 \AA$ and also close value of polydispersity within error, ranging from $3.3 \%$ to $4.5 \%$ (Table 3 ).

\subsection{Evaluation of the structural organization by small-angle X-ray scattering}

In order to gain more insight on the structural organization of the insulin products in their pharmaceutical formulation, we have performed small-angle X-ray scattering (SAXS) measurements, at two different SAXS beamlines using two distinct insulin batches from each product. In particular, SAXS has long being used to identify the quaternary organization of proteins, including insulin and insulinomimetic compounds at varying compositions [56-58]. 
A

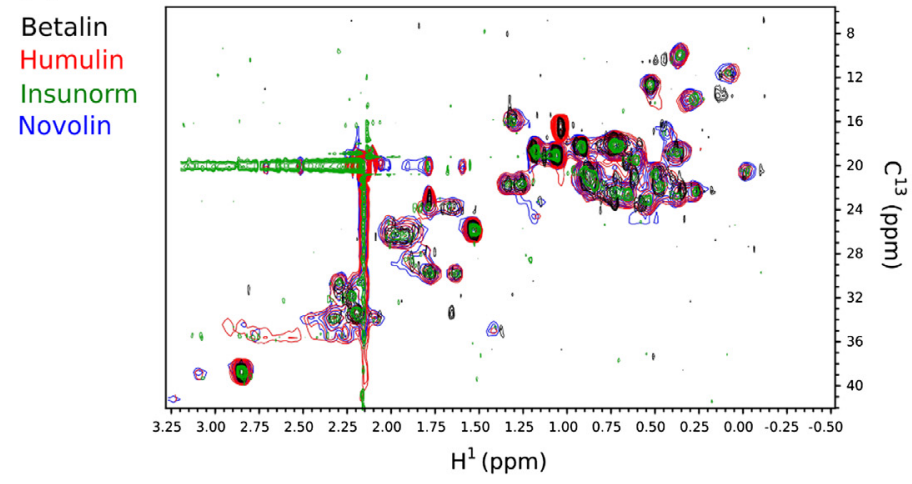

C

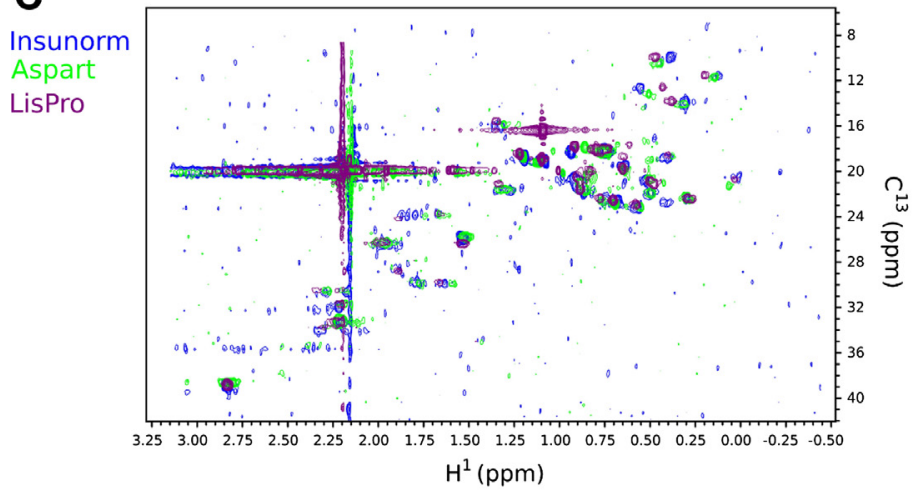

E

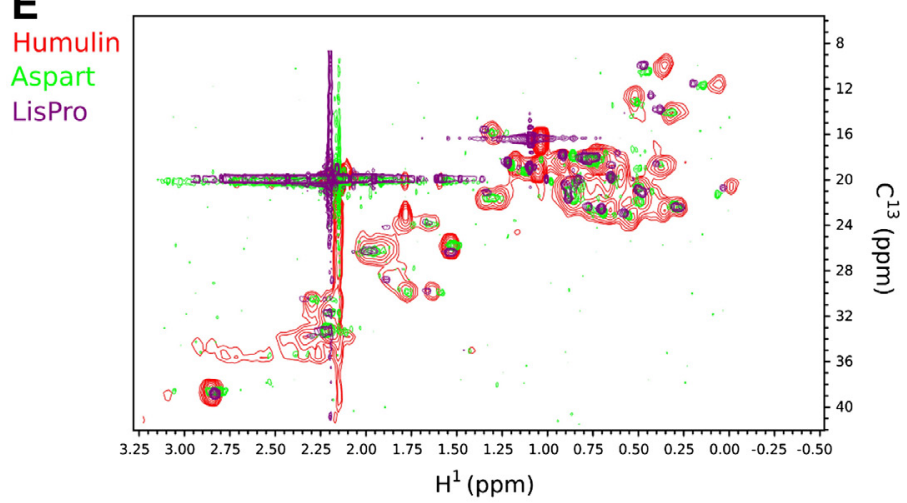

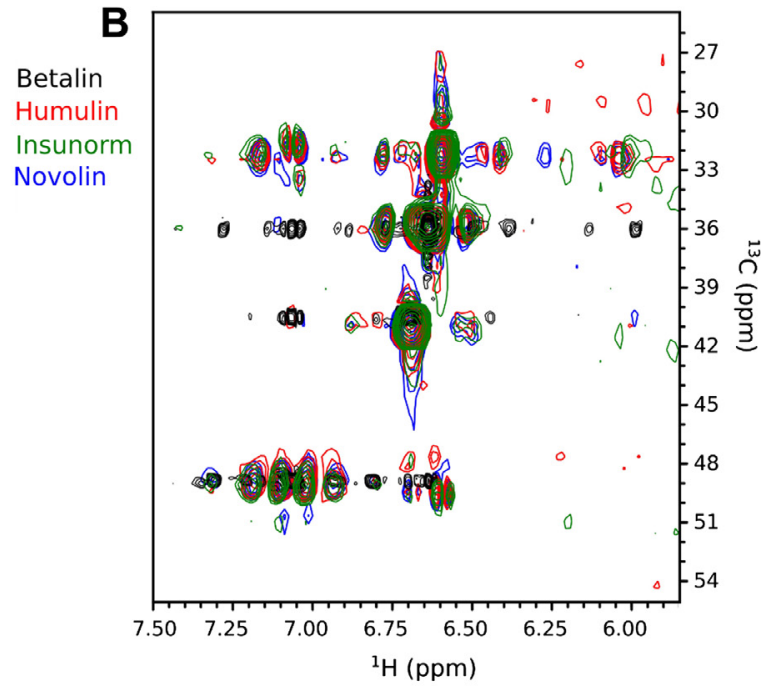
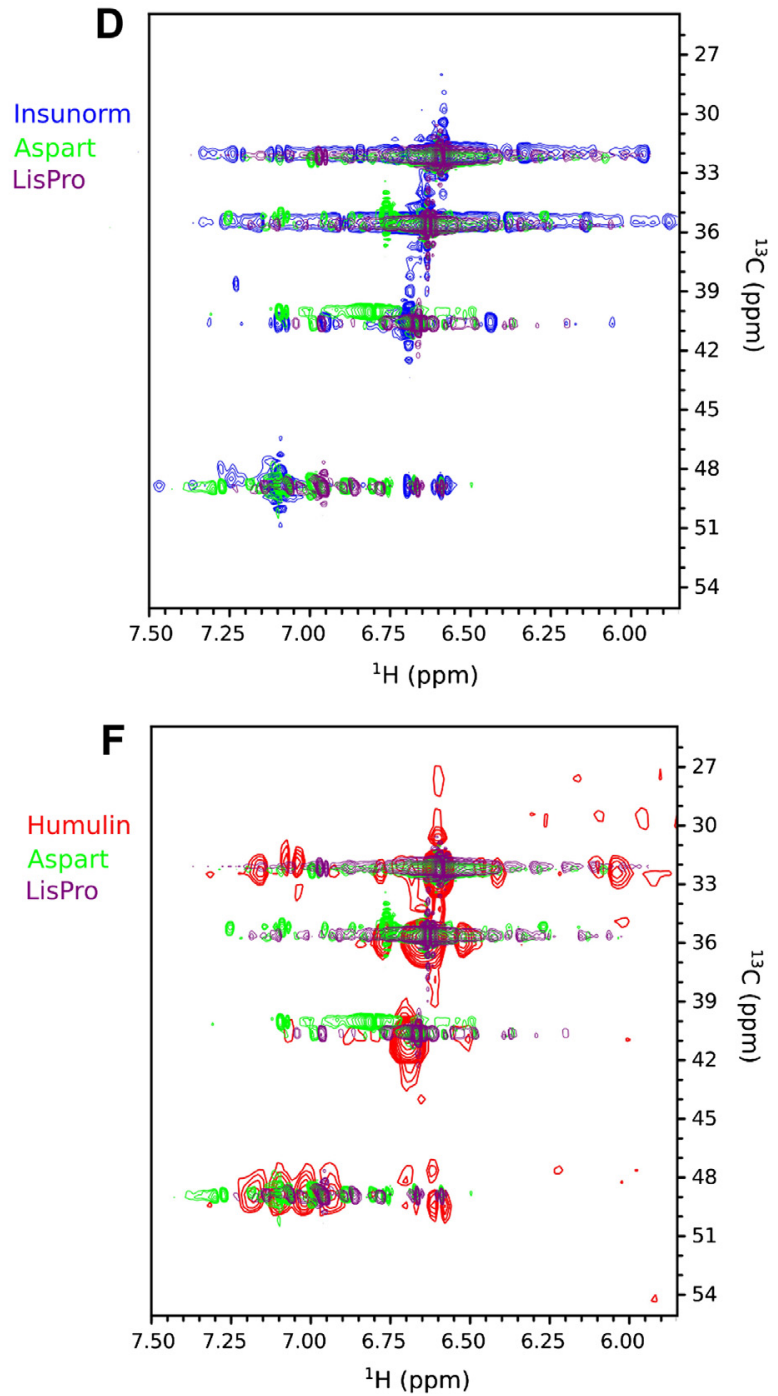

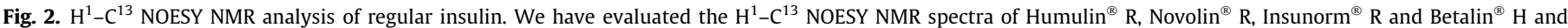

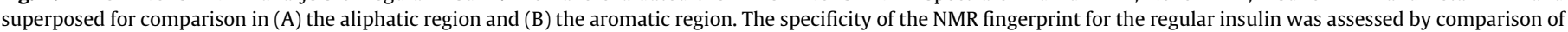

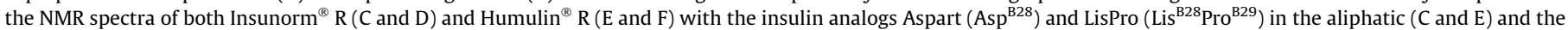
aromatic (D and F) regions. Colors are as indicated in the figure. Details in Section 2. 
The SAXS data evidenced the similarity between the four insulin products (Fig. 1), suggesting equivalent molecular envelopes and oligomeric state, which is expected to be a hexamer under formulation condition [59]. The concentration dependence of the scattering profile was probed by measuring SAXS of the insulin formulation at their original concentration $(100 \mathrm{U} / \mathrm{mL}$; Fig. $1 \mathrm{~A}, \mathrm{~B}, \mathrm{D}, \mathrm{E}, \mathrm{G}$, and $\mathrm{H}$ ) and diluted (33 U/mL; Fig. $1 \mathrm{C}, \mathrm{F}$ and I). Analysis of the SAXS data revealed the lack of effects from dilution at this concentration range on changes in the insulin scattering and thus in its conformation and oligomeric state. This behavior was equivalent for all four insulin products, for two distinct batches measured each at distinct beamlines (Fig. 1A, D and $G$ versus Fig. 1B, E and $H$ ).

The Guinier analysis, shown as the dependence of the log of scattering intensity on the $q^{2}$ vector [40], revealed a monodisperse system as judged by the lack of any drift in the linearity, suggesting a single oligomeric form in solution and the absence of detectable aggregate (Fig. 1A-C, inset). There were only minor changes within error in main parameters such as the radii of gyration and $D_{\max }$ (Table 4). The Guinier analysis and real space analysis obtained from the Fourier transform of the scattering profile using Gnom [41] allowed the recovery of structural parameters from the protein particle such as the maximum distance in the $\left(D_{\max }\right)$ and the radii of gyration $(\mathrm{Rg})$, which provided to be the same within error for all insulin formulations evaluated here (Table 4). The obtained pair-distribution function $P(r)$ also revealed similar molecular shape for all four formulations, both at their original formulation (Fig. 1D and E) and diluted (Fig. 1F), ruling out any concentration-dependent effects at the present analytical conditions. The Kratky plot of the scattering profile reveals a bell-shaped profile, which is characteristic of globular particles with no flexible domains (Fig. 1F-H) [40]. These behaviors were similar for the four insulin formulations at both concentrations, indicating a similarity between them in oligomeric state, particle form and globularity in solution.

\subsection{Solution characterization by nuclear magnetic resonance}

In order to gain insight into the overall conformation of the insulin formulations, we have performed natural abundance ${ }^{1} \mathrm{H}-{ }^{13} \mathrm{C}-\mathrm{HSQC}$ of these products. This approach allows the detection of all ${ }^{1} \mathrm{H}-{ }^{13} \mathrm{C}$ chemical moieties and was previously used by other for the structural characterization of human, porcine, and bovine insulin $[31,60,61]$. In the spectra of the four regular insulin, the observed crosspeaks are well defined, few and dispersed, as expected for a small, well folded protein, with a sharply defined conformation rather than an ensemble of different conformational populations in solution.

The ${ }^{1} \mathrm{H}-{ }^{13} \mathrm{C}-\mathrm{HSQC}$ spectra of all four regular insulin are superimposable, showing similar patterns of intensity and distribution of crosspeaks in both the aliphatic (Fig. 2A) and the aromatic (Fig. 2B) regions. The signal from aromatic compounds found in insulin formulations (such as phenol and $\mathrm{m}$-cresol) did not interfere in the NMR analysis, since they are found outside the spectral window reported here (http://www.bmrb.wisc.edu/). The methyl carbon of m-cresol has a carbon chemical shift of $23.09 \mathrm{ppm}$ and a proton chemical shift of $2.28 \mathrm{ppm}$. This crosspeak is readily observable in ${ }^{13} \mathrm{C}$-HSQC insulin spectrum, but without interference of protein signals.

In order to evaluate the specificity of the ${ }^{1} \mathrm{H}-{ }^{13} \mathrm{C}-\mathrm{HSQC}$ NMR measurements for probing specific conformation of the insulin products in their finished solution, we have compared the spectra obtained from one regular insulin with two insulin analogs, the Aspart $\left(\mathrm{Asp}^{\mathrm{B} 28}\right)$ and insulin LisPro $\left(\mathrm{Lis}^{\mathrm{B} 28}-\mathrm{Pro}^{\mathrm{B} 29}\right)$, two engineered variants used as a fast-acting insulin. Both insulin analogs were well folded in their original solution, as indicated by their NMR spectra. Superposition of the NMR spectrum of the analogs with the regular human insulin evidenced divergences between them both in the aliphatic (Fig. 2C and E) and in the aromatic (Fig. 2D and $\mathrm{F}$ ) regions, suggesting dissimilar conformation in solution between the regular insulin and the analogs. Collectively, these data
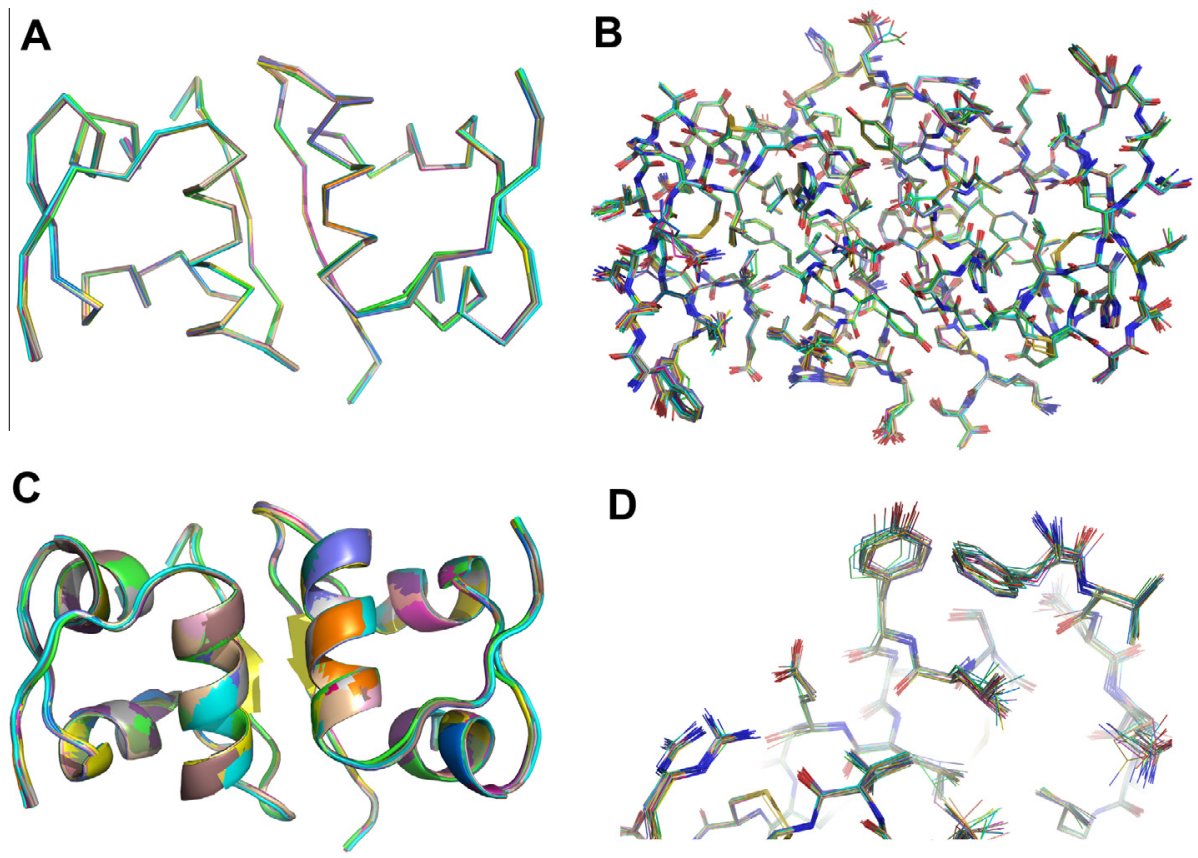

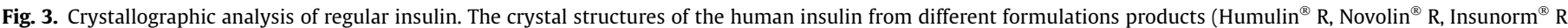

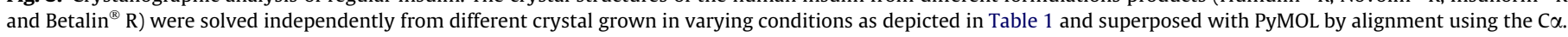

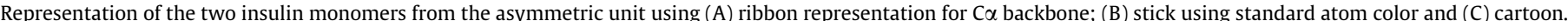

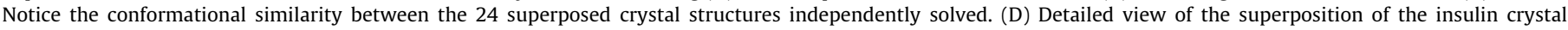
structures, showing the positional variability of the side chains at the protein surface. Details in Section 2. 


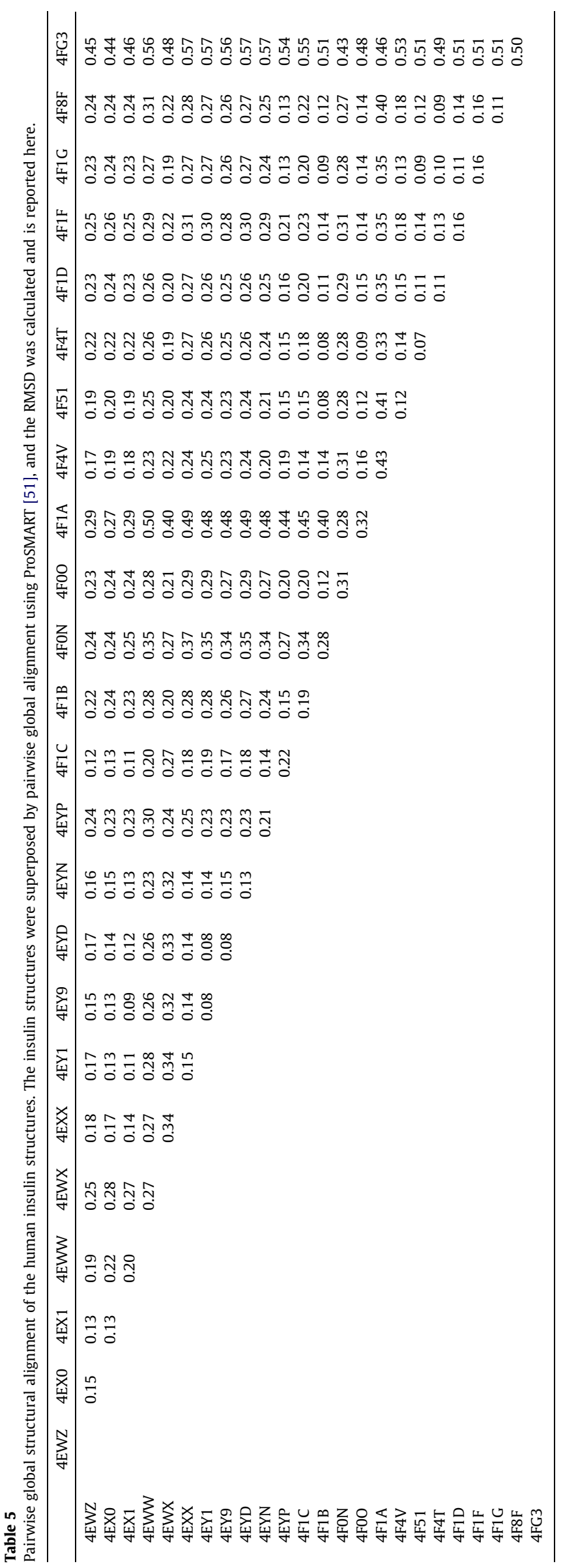

provide further evidences for conformational similarity between the regular-acting human insulin products in solution and their dissimilarity with the insulin analogs, indicating the specificity and robustness of the NMR fingerprint approach in the identification of insulin conformation in the finished product.

\subsection{Crystal structure of human insulin from final therapeutic formulation}

In order to access the high resolution structure of the human insulin in their final formulated products, we have performed a systematic, matrix-based crystallization screening for crystallization conditions using the minimal amount of additives, mainly by screening for $\mathrm{pH}$ and traditional precipitant agents, such as polyethyleneglycol, $\mathrm{NaCl}$, and $\left(\mathrm{NH}_{4}\right)_{2} \mathrm{SO}_{4}$. We have also limited our screening to the traditional vapor-diffusion methods (sitting and hanging drop), using equal volume of insulin formulations and precipitant solution from well (see Section 2), and equilibrating for no longer than 10 days.

In this approach, we have found several crystallization conditions for the human insulin from their formulated products. Crystal diffraction analysis revealed that the best diffraction quality crystals were obtained from mother liquor containing either PEG 400 or PEG $6 \mathrm{~K}$ at about $10 \%$ as precipitant and with $\mathrm{pH} 5.5$, an optimum $\mathrm{pH}$ for insulin stabilization [62] and equals to its isoeletric point, $\mathrm{pI}=5.51$ [59]. The best quality diffraction data could also be achieved by supplementing the mother liquor with $10 \% \mathrm{v} /$ $\mathrm{v}$ glycerol as cryoprotectant just prior flash freezing the crystal. Lower glycerol concentration resulted in strong ice diffraction while higher glycerol contents resulted in the decrease in protein diffraction power (data not shown).

The four regular human insulin formulation tested here resulted in insulin crystal belonging to the space group R3 (Table S1). The asymmetric unit is comprised by two insulin monomers (each one with chains $\mathrm{A}$ and $\mathrm{B}$ ), which results in the insulin hexamer with the symmetry-related molecules. We have diffracted and solved 24 structures from several insulin crystals for each product using varying diffraction setups (as depicted in Section 2) and data integration, scaling, molecular replacement and real and reciprocal space refinement approaches, conducted without any semi-automated or any sort of systematic approach. This strategy allows attaining better clarity of the crystal structures, minimizing the uncertainty caused by interpretation of a single model [56,63-65], providing an ensemble of structural models revealing eventual mobility distribution, and also minimizing the analytical errors associated with the crystallography technique [66].

All four regular insulin resulted in similar crystal structures (Fig. 3) at the same point group and with similar cell parameters (Table S1), irrespective to differences in their formulation and manufacturing process and crystallization variables as depicted below. A pairwise global structural alignment of the insulin structures reveals equivalent structure (Table 5; Fig. 3A-C), with global RMSD of less than $0.5 \AA$ (Table 5), average global RMSD of less than $0.3 \AA$ (Table 6 ) and C $\alpha$ RMSD of less than $0.3 \AA$, regardless of the additional tested variables on the crystallization of the human insulin products evaluated here, such as the composition of the crystallization mother liquor on the human insulin crystal structures, by probing for changes in the buffer (from phosphate to citrate) and in the precipitant (from PEG 6K to PEG 400), growing time until harvesting for freezing in $\mathrm{N}_{2}$ liq (2 days and 7 days), crystallization method (hanging versus sitting drops), temperature $\left(18-25^{\circ} \mathrm{C}\right)$, drop size $(2 \mu \mathrm{L}, 4 \mu \mathrm{L})$, cooling method (direct cooling under nitrogen stream or flash cooling by immersion into liquid nitrogen followed by transfer to nitrogen stream at $100 \mathrm{~K}$ for diffraction experiment), glycerol concentration as cryoaddi- 
Table 6

Pairwise global structural alignment of the human insulin structures. The insulin structures were superposed by pairwise global alignment using ProSMART [51], and the RMSD was calculated and reported in Table 5. The mean value and standard deviation for the RMSD for each subgroup as defined in Table 5 is reported here.

\begin{tabular}{lllll}
\hline & Betalin & Insunorm & Novolin & Humulin \\
\hline Betalin & $0.21 \pm 0.06$ & $0.21 \pm 0.08$ & $0.25 \pm 0.08$ & $0.26 \pm 0.09$ \\
Insunorm & & $0.16 \pm 0.06$ & $0.30 \pm 0.11$ & $0.28 \pm 0.11$ \\
Novolin & & & $0.29 \pm 0.10$ & $0.25 \pm 0.13$ \\
Humulin & & & & $0.22 \pm 0.17$ \\
\hline
\end{tabular}

tive (5-10\%). Minor positional variations of human insulin side chains were observed, mainly in the protein surface (Fig. 3B and D), revealing a larger dynamics of the protein at this region. All crystal structures of the regular human insulin were found with the two insulin monomers of the asymmetric unit in the " $\mathrm{T}$ " state, i.e., with the region B1 to B8 in an extended conformation (Fig. 3C).

The insulin structures show also two zinc ions, each coordinated by the $\mathrm{His}^{\mathrm{B} 10}$ from each insulin monomer and by additional chloride ions (not shown). In one (4FG3.pdb) of the crystal structures reported here, we were able to model a glycerol molecule, which was found lying between the $\mathrm{His}^{\mathrm{B} 5}$ and the $\mathrm{Gln}^{\mathrm{B} 4}$ (not shown). We were not able to find any electron density blob compatible with either metacresol or phenol in any particular region of the crystallographic protein structure. No other ligand could be modeled in the remaining electron density map.

Further attempts to grow crystals from the insulin analogs Lis $^{\mathrm{B} 28}$-Pro $^{\mathrm{B} 29}$ (insulin LisPro) and from Asp ${ }^{\mathrm{B} 28}$ (insulin Aspart) pharmaceutical products using the above mentioned crystallization conditions were unsuccessful (not shown). The failure in crystallizing the insulin analogs using the same experimental approach applied for the regular human insulin indicates that only minor association and packing effects during the crystallization process would be governing its final conformation. Altogether, these data indicate that the present crystallization method reported here are sufficiently robust and specific as a bioanalytical method for the determination of the high resolution structure of wild-type human insulin direct from pharmaceutical formulations.

\section{Discussion}

The first insulin crystal structure has been obtained about 50 years ago [67], since the first attempts decades before [68], by using the traditional batch annealing crystallization technique [69], comprising heating and cooling of insulin solution. Since them, spectroscopic and crystallographic techniques have been applied to exploit the structure and conformational transition in insulin and their correlation with biological activity [33,57,7077]. More recently, X-ray powder-diffraction from microcrystalline material has also been show to be effective in the elucidation of insulin structure [28] and also accurately used in the determination of dissimilar polymorphic forms of insulin formulations $[78,79]$.

Since the seminal description of the production of insulin and its therapeutic use in the management of diabetes [14], several insulin products have been developed, and heterologous insulin has been mostly replaced by human insulin produced from distinct methods and formulated with varying excipient composition, either by recombinant expression in E. coli, S. cerevisae, and P. pastoris or by semi-synthetic preparation from porcine insulin [8086]. The large number of variables in the production of therapeutic biological agents can impact directly over their quality, efficacy, and safety $[20,87,88]$. Relying on the protein structure-function paradigm, these parameters are intrinsically related to the chemical and structural integrity. In this context, while many pharmaco- peical analytical and bioanalytical methods are available for the quality assessment of insulin products, it is highly desirable exploiting the three-dimensional structure of protein in its final formulations in order to ensure the appropriate folding and quaternary assembly and thus the biological function. The use of conformational and high-resolution structural information has been suggested as a requirement for the comparability evaluation of biological follow-on products [89-93]. However, to date no high-resolution structural requirement is made for human insulin in the current US, European, Japanese, and Brazilian pharmacopeias. Instead, the biological and, indirectly, the structural integrity of insulin are indirectly accessed through biological assays, with the single-point evaluation of the glycemia lowering efficiency by insulin products, along with other biochemical proofs of purity and potency.

In the present study, we have made the combined use of modern state-of-the-art structural techniques (mass spectrometry, dynamic light scattering, small-angle X-ray scattering, nuclear magnetic resonance, and protein crystallography) for the detailed characterization of the chemical and structural integrity, accessing the correct folding through the evaluation of the secondary, tertiary, and quaternary structural arrangement of the human insulin in four distinct pharmaceutically available products from varying brands, differing completely in formulation composition, expression system and purification procedures, formulated to the same potency.

We have achieved a satisfactory crystallization approach which combine technical feasibility (as shown by the crystallization method: vapor diffusion and simple precipitant composition), reproducibility and robustness (as shown by solving their structures from crystals obtained from varying batches of both insulin and chemicals, crystal grow temperature, different producers, $\mathrm{X}$ ray sources, detectors, freezing methods, and different analysts), and by its selectivity (as shown by the lack of crystallization of two insulin analogs, aspart - Asp ${ }^{\mathrm{B} 28}$ - and LisPro - $\mathrm{Lys}^{28 \mathrm{~B}} \mathrm{Pro}^{29 \mathrm{~B}}$ ). The present crystallization approach resulted in good diffracting quality crystals within a few days for all regular human insulin products, both presenting same space group, similar cell parameters and conformation. All structures consist of two insulin monomers and two zinc atoms per asymmetric unit coordinate by the $\mathrm{His}^{\mathrm{B} 10}$. The overall conformations of both insulin monomers are similar, with C $\alpha$ RMSD of less than $0.3 \AA$.

All the 24 crystal structures reported here were in the $T(6)$ state, i.e., with the six monomers of the hexamer in the T state, with the B1 to B8 segment in extended form. This conformation is typical of the insulin in the absence of phenolic compounds, while the R state is achieved by the interaction with phenolic compounds. The concentration of phenolic compounds and zinc in the formulations studied here are supposed to be sufficient to achieve saturation in the $\mathrm{T} \rightarrow \mathrm{R}$ transition [94] at pH 7.4. However, the present crystallization procedure used here involves the use of buffers at pH 5.5 and other components of the mother liquor. These variables could diminish the free energy of transition from the $\mathrm{R}$ to the $\mathrm{T}$ state, resulting in the $T(6)$ conformer observed in the crystal structures reported here. At present, it is not possible to precise the mechanisms for this finding. Although the crystallization process might introduce some sort of drift in the conformational transition of insulin, the crystallization procedure seems to be well selective for the present conformer observed here for the regular insulin, since the insulin analogs Aspart and LisPro could not be crystallized using the same approach.

Along with the crystallographic evidences for the structure of insulin obtained from the final formulated products, NMR could also be a useful reference for crosspeaks arising from the aromatic carbons. Differences in primary structure can be precisely detected in these NMR experiments. Also, a fingerprint of the primary struc- 
ture and global folding can be generated [95,96], enabling a rapid assay to compare different products or to monitor the chemical and folding integrity of insulin samples. The 2D-NMR spectra can be used as "fingerprints" for topological characterization of insulin in the final pharmaceutical formulation, sensible enough to detect subtle differences as mutations, different side chain packing, or small differences in folding. These data support the use of ${ }^{1} \mathrm{H}-{ }^{13} \mathrm{C}-\mathrm{HSQC}$ NMR spectra as a survey for the insulin conformation in solution, as a conformational fingerprint. NMR and crystallography are very complementary techniques in the elucidation of the high resolution protein structure [31,56,97-100]. The combination of crystal structure from single crystals obtained from final formulation and the NMR fingerprints can assist in further routine analysis of insulin products and formulation studies.

Government initiatives at several nations have motivated the development of biological follow-on products including insulin [90-93,101-103] which has allowed the approval of several products in the European Union Health Agency since 2005 and one in Brazil [104-107]. Complimentary to the use of the present structural approaches for quality assessment of insulin in its final formulated product, these data could be used in the structural comparability exercises of insulin products, which in special given the fact that they all share the very same chemical identity. Moreover, it has been reported the similarity in the biological activity of regular acting human insulin products in vivo [108,109]. Other studies have suggested the need of extensive characterization for biosimilar $[110,111]$. However, we understand that similar conformation does not preclude exact biological activity, since distinct formulation could modify protein properties in the administration site and beyond, such as the kinetic release, absorption, and interaction with molecular partners [74,88,108,112-116]. Additional biological and non-inferiority clinical evaluation should be addressed in conjunction with structural information in comparability studies.

These combined methods can assist in the determination of chemical integrity (mass spectrometry), solution conformation (NMR fingerprint), and structural integrity (NMR and X-ray crystallography) of regular acting human insulin in final formulations. These structural methods are currently well-established, and they can be accessed in most countries, in special those for the main pharmaceutical markets, the Americas, Europe and Japan, whose pharmacopeias were above mentioned. It could be used in routine evaluation of structural integrity and identity, as a part of current or evolving methods aiming the minimization of animals' requirement in routine quality control, in the development of novel insulin products, or in future protocols for a thorough comparability exercises between follow-on protein product and a reference product. We believe that the information gathered in the present study would assist in further establishment of biological structural standards for routine pharmacopeical and metrological quality analysis.

\section{Acknowledgements}

We would like to thank Dr. Patricia R. Guimarães and Dr. Russolina B. Zingali (Proteomic Facility at IBqM-UFRJ), Dr. Fernando de Mattos and Dr. Walan Grizolli (LNLS) for excellent support at the respective facilities. This research was supported by Instituto Nacional de Traumato-Ortopedia (INTO-MS-Brasil), Coordenação de Aperfeiçoamento de Pessoal de Nível Superior (CAPES); Conselho Nacional de Desenvolvimento Científico e Tecnológico (CNPq), INCT-CNPq; Fundação de Amparo à Pesquisa do Estado do Rio de Janeiro Carlos Chagas Filho (FAPERJ), Brazillian Synchrotron Light Laboratory (LNLS) and Instituto Nacional de Metrologia, Normalização e Qualidade Industrial (INMETRO). Funding agencies had no role in study design, data collection, and analysis.

\section{Appendix A. Supplementary material}

Supplementary data associated with this article can be found, in the online version, at http://dx.doi.org/10.1016/j.ejpb.2013.05.005.

\section{References}

[1] G. Danaei, M.M. Finucane, Y. Lu, G.M. Singh, M.J. Cowan, C.J. Paciorek, J.K. Lin, F. Farzadfar, Y.H. Khang, G.A. Stevens, M. Rao, M.K. Ali, L.M. Riley, C.A. Robinson, M. Ezzati, Lancet 378 (2011) 31-40.

[2] R.H. Lustig, L.A. Schmidt, C.D. Brindis, Nature 482 (2012) 27-29.

[3] M. Eisenstein, Nat. Biotechnol. 29 (2011) 782-785.

[4] F. Thorel, V. Nepote, I. Avril, K. Kohno, R. Desgraz, S. Chera, P.L. Herrera, Nature 464 (2010) 1149-1154.

[5] Y. Lee, M.Y. Wang, X.Q. Du, M.J. Charron, R.H. Unger, Diabetes 60 (2011) 391397.

[6] F. Waldron-Lynch, K.C. Herold, Nat. Rev. Drug Discov. 10 (2011) 439-452.

[7] S. Aldridge, Nat. Biotechnol. 30 (2012) 124.

[8] Nat. Rev. Drug Discov. 9 (2010) 422. <http://www.nature.com/nrd/journal/ v9/n6/full/nrd3197.html>.

[9] R.A. Bagarolli, M.J. Saad, S.T. Saad, J. Diabetes Complicat. 24 (2010) 192-198

[10] F.G. Eliaschewitz, C.A. Aita, T. Genzini, I.L. Noronha, F.H. Lojudice, L. Labriola, K. Krogh, E.M. Oliveira, I.C. Silva, Z. Mendonca, D. Franco, M.P. Miranda, E. Noda, L.A. de Castro, M. Andreolli, A.C. Goldberg, M.C. Sogayar, Transplant. Proc. 36 (2004) 1117-1118

[11] S.C. Gunawardana, D.W. Piston, Diabetes 61 (2012) 674-682.

[12] A. Young, Amylin: Physiology and Pharmacology, Elsevier Academic Press, 2005.

[13] L.H. Guerreiro, S.D. Da, E. Ricci-Junior, W. Girard-Dias, C.M. Mascarenhas, M Sola-Penna, K. Miranda, L.M. Lima, Colloids Surf., B Biointerface 94 (2012) 101-106.

[14] C.H. Best, D.A. Scott, The preparation of insulin, J. Biol. Chem. 57 (1923) 709723.

[15] T.D. Coan, R. Ellis, ABN AMRO Bank NV - Generic Biologics: the Next Frontier 2001, pp. 1-38. <http://www.cptech.org/ip/health/biotech/ genbio062001.pdf> (ABN AMRO Bank NV).

[16] E. Chantelau, Lancet 355 (2000) 2166.

[17] C.G. Cameron, H.A. Bennett, CMAJ 180 (2009) 400-407.

[18] J. Kling, Nat. Biotechnol. 26 (2008) 479-480.

[19] P.V. Finotelli, S.D. Da, M. Sola-Penna, A.M. Rossi, M. Farina, L.R. Andrade, A.Y. Takeuchi, M.H. Rocha-Leao, Colloids Surf., B Biointerface 81 (2010) 206-211.

[20] A.S. Rathore, H. Winkle, Nat. Biotechnol. 27 (2009) 26-34.

[21] The United States Pharmacopeia - National Formulary, The U.S Pharmacopoeia and National Formulary, United States Pharmacopeial, 2011.

[22] L.C. Palmieri, M.P. Favero-Retto, D. Lourenco, L.M. Lima, Biophys. Chem. 173 (174C) (2013) 1-7

[23] R. Salbo, M.F. Bush, H. Naver, I. Campuzano, C.V. Robinson, I. Pettersson, T.J Jorgensen, K.F. Haselmann, Rapid Commun. Mass Spectrom. 26 (2012) 11811193.

[24] J.J. Abel, Proc. Natl. Acad. Sci. USA 12 (1926) 132-136.

[25] D.A. Scott, A.M. Fisher, Biochem. J. 29 (1935) 1048-1054.

[26] M. Hallas, K. Petersen, J. Schlichtkrull, Science 116 (1952) 394-398.

[27] T.L. Blundell, J.F. Cutfield, S.M. Cutfield, E.J. Dodson, G.G. Dodson, D.C. Hodgkin, D.A. Mercola, M. Vijayan, Nature 231 (1971) 506-511.

[28] R.B. Von Dreele, P.W. Stephens, G.D. Smith, R.H. Blessing, Acta Crystallogr. D Biol. Crystallogr. 56 (2000) 1549-1553.

[29] H.B. Olsen, S. Ludvigsen, N.C. Kaarsholm, Biochemistry 35 (1996) 8836-8845

[30] P.S. Brzovic, W.E. Choi, D. Borchardt, N.C. Kaarsholm, M.F. Dunn, Biochemistry 33 (1994) 13057-13069.

[31] X.Q. Chang, A.M.M. Jorgensen, P. Bardrum, J.J. Led, Biochemistry 36 (1997) 9409-9422.

[32] A.D. Kline, R.M. Justice Jr., Biochemistry 29 (1990) 2906-2913. <http:// pubs.acs.org/doi/abs/10.1021/bi00464a003?journalCode=bichaw>.

[33] Q. Hua, S.E. Shoelson, M. Kochoyan, M.A. Weiss, Nature 354 (1991) 238-240.

[34] Q. Hua, M.A. Weiss, Biochemistry 30 (1991) 5505-5515.

[35] R.M. Knegtel, R. Boelens, M.L. Ganadu, R. Kaptein, Eur. J. Biochem. 202 (1991) 447-458.

[36] W. Kadima, M. Roy, R.W. Lee, N.C. Kaarsholm, M.F. Dunn, J. Biol. Chem. 267 (1992) 8963-8970.

[37] J.L. Whittingham, D.J. Edwards, A.A. Antson, J.M. Clarkson, G.G. Dodson, Biochemistry 37 (1998) 11516-11523.

[38] E. Ciszak, J.M. Beals, B.H. Frank, J.C. Baker, N.D. Carter, G.D. Smith, Structure 3 (1995) 615-622.

[39] G. Kellermann, F. Vicentin, E. Tamura, M. Rocha, H. Tolentino, A. Barbosa, A. Craievich, I. Torriani, J. Appl. Crystallogr. 30 (1997) 880-883.

[40] A. Guinier, G. Fournet, Small-angle Scattering of X-rays, John Wiley \& Sons, NY (1-1-1955).

[41] D.I. Svergun, J. Appl. Crystallogr. 25 (1992) 495-503.

[42] I. Polikarpov, L.A. Perles, R.T. de Oliveira, G. Oliva, E.E. Castellano, R.C. Garratt, A. Craievich, J. Synchrotron. Radiat. 5 (1998) 72-76.

[43] B.G. Guimaraes, L. Sanfelici, R.T. Neuenschwander, F. Rodrigues, W.C. Grizolli, M.A. Raulik, J.R. Piton, B.C. Meyer, A.S. Nascimento, I. Polikarpov, J. Synchrotron. Radiat. 16 (2009) 69-75.

[44] A.G. Leslie, Joint CCP4 + ESF-EAMCB Newsl. Protein Crystallogr. (1992) 
[45] Agilent Technologies, CrysAlisPro Software system 2011, Oxford, UK, Agilent Technologies UK Ltd., 2011 (1.171.35.19).

[46] P.R. Evans, Joint CCP4 ESF-EACBM Newsl. Protein Crystallogr. 33 (1997) 22 24.

[47] A. Vagin, A. Teplyakov, J. Appl. Crystallogr. 30 (1997) 1022-1025.

[48] A.J. McCoy, R.W. Grosse-Kunstleve, P.D. Adams, M.D. Winn, L.C. Storoni, R.J Read, J. Appl. Crystallogr. 40 (2007) 658-674

[49] G.N. Murshudov, A.A. Vagin, E.J. Dodson, Acta Crystallogr. D Biol. Crystallogr. 53 (1997) 240-255.

[50] P. Emsley, K. Cowtan, Acta Crystallogr. D Biol. Crystallogr. 60 (2004) 21262132.

[51] R.A. Laskowski, M.W. MacArthur, D.S. Moss, J.M. Thornton, J. Appl. Crystallogr. 26 (1993) 283-291.

[52] W.L. DeLano, The PyMOL Molecular Graphics System, DeLano Scientific LLC, San Carlos, CA, USA, 2002.

[53] R.A. Nicholls, Conformation-Independent Comparison of Protein Structures, University of York, 2011.

[54] F. Delaglio, S. Grzesiek, G.W. Vuister, Z. Guang, J. Pfeifer, A. Bax, J. Biomol. NMR 6 (1995) 277-293.

[55] R.L.J. Keller, Optimizing the Process of Nuclear Magnetic Resonance Spectrum Analysis and Computer Aided Resonance Assignment, 2004.

[56] L.M. Lima, C.F. Becker, G.M. Giesel, A.F. Marques, M.T. Cargnelutti, N.M. de Oliveira, R.Q. Monteiro, H. Verli, I. Polikarpov, Biochim. Biophys. Acta 1794 (2009) 873-881.

[57] V.N. Uversky, L.N. Garriques, I.S. Millett, S. Frokjaer, J. Brange, S. Doniach, A.L. Fink, J. Pharm. Sci. 92 (2003) 847-858.

[58] L. Nielsen, S. Frokjaer, J. Brange, V.N. Uversky, A.L. Fink, Biochemistry 40 (2001) 8397-8409.

[59] J.P. Richards, M.P. Stickelmeyer, D.B. Flora, R.E. Chance, B.H. Frank, M.R. DeFelippis, Pharm. Res. 15 (1998) 1434-1441.

[60] K.A. Higgins, D.J. Craik, J.G. Hall, P.R. Andrews, Drug Des. Deliv. 3 (1988) 159170.

[61] S.M. Kristensen, A.M. Jthetargensen, J.J. Led, P. Balschmidt, F.B. Hansen, J. Mol. Biol. 218 (1991) 221-231.

[62] C. Bryant, D.B. Spencer, A. Miller, D.L. Bakaysa, K.S. McCune, S.R. Maple, A.H. Pekar, D.N. Brems, Biochemistry 32 (1993) 8075-8082.

[63] N. Furnham, T.L. Blundell, M.A. Depristo, T.C. Terwilliger, Nat. Struct. Mol. Biol. 13 (2006) 184-185.

[64] P. Gros, W.F. van Gunsteren, W.G.J. Hol, Science 249 (1990) 1149-1152.

[65] T.C. Terwilliger, R.W. Grosse-Kunstleve, P.V. Afonine, P.D. Adams, N.W. Moriarty, P. Zwart, R.J. Read, D. Turk, L.W. Hung, Acta Crystallogr. D Biol. Crystallogr. 63 (2007) 597-610.

[66] K. Diederichs, Acta Crystallogr. D Biol. Crystallogr. 66 (2010) 733-740.

[67] M.J. Adams, T.L. Blundell, E.J. Dodson, G.G. Dodson, M. Vijayan, E.N. Baker, M.M. Harding, D.C. Hodgkin, B. Rimmer, S. Sheat, Structure of rhombohedral 2 zinc insulin crystals, Nature 224 (1969) 491-495.

[68] D. Crowfoot, X-ray single crystal photographs of insulin, Nature 135 (1935) 591-592.

[69] M.M. Harding, D.C. Hodgkin, A.F. Kennedy, A. O'Conor, P.D. Weitzmann, J. Mol. Biol. 16 (1966) 212-226.

[70] S.A. Chawdhury, E.J. Dodson, G.G. Dodson, C.D. Reynolds, S.P. Tolley, T.L. Blundell, A. Cleasby, J.E. Pitts, I.J. Tickle, S.P. Wood, Diabetologia 25 (1983) 460-464.

[71] R.A. Pullen, D.G. Lindsay, S.P. Wood, I.J. Tickle, T.L. Blundell, A. Wollmer, G. Krail, D. Brandenburg, H. Zahn, J. Gliemann, S. Gammeltoft, Nature 259 (1976) 369-373.

[72] H. Renscheidt, W. Strassburger, U. Glatter, A. Wollmer, G.G. Dodson, D.A. Mercola, Eur. J. Biochem. 142 (1984) 7-14.

[73] S.P. Wood, T.L. Blundell, A. Wollmer, N.R. Lazarus, R.W. Neville, Eur. J. Biochem. 55 (1975) 531-542.

[74] R.E. Chance, E.P. Kroeff, J.A. Hoffmann, B.H. Frank, Diabetes Care 4 (1981) $147-154$.

[75] U. Derewenda, Z. Derewenda, E.J. Dodson, G.G. Dodson, X. Bing, J. Markussen, J. Mol. Biol. 220 (1991) 425-433.

[76] U. Derewenda, Z. Derewenda, E.J. Dodson, G.G. Dodson, C.D. Reynolds, G.D. Smith, C. Sparks, D. Swenson, Nature 338 (1989) 594-596.

[77] U. Derewenda, Z. Derewenda, G.G. Dodson, R.E. Hubbard, F. Korber, Br. Med. Bull. 45 (1989) 4-18.

[78] M. Norrman, K. Stahl, G. Schluckebier, S. Al-Karadaghi, J. Appl. Crystallogr. 39 (2006) 391-400.

[79] J.P. Richards, M.P. Stickelmeyer, B.H. Frank, S. Pye, M. Barbeau, J. Radziuk, G.D. Smith, M.R. DeFelippis, J. Pharm. Sci. 88 (1999) 861-867.

[80] S.A. Filho, B.D. Lima, J.E. Thiemann, H.R.T. Sousa, L. Vilela, Vector for Expression of Heterologous Protein and Methods for Extracting Recombinant Protein and for Purifying Isolated Recombinant Insulin, Biobras SA, Universidade de Brasilia, 08/886967[6068993], 5-30-2000, Minas Gerais/Brazil, 7-2-1997.

[81] A.D. Riggs, Method for Microbial Polypeptide Expression, Genentech, Inc So 90980[US4366246], California/USA, 11-5-1979, 1982.
[82] J. Markussen, Process for Preparing Esters of Human Insulin, Novo Industri A/ S, 233051[US4343898], 8-10-1982, Denmark, pp. 1-9.

[83] J. Markussen, N. Fill, M.T. Hansen, K. Norris, G. Ammerer, L. Thim, H.O. Voigt, DNA-sequence Encoding Biosynthetic Insulin Precursors and Process for Preparing The Insulin Precursors and Human Insulin, Novo Industri A/S. 739123[US 4916212], 4-10-1990, Denmark. 5-29-1985, pp. 1-21.

[84] N. Annibali, Expression of a Human Insulin Precursor in P. pastoris, Laboratorios Beta, 09/955259[US7091032], 6-5-2003, Argentina, Ref Type: Patent, pp. 1-20.

[85] D.V. Goeddel, D.G. Kleid, F. Bolivar, H.L. Heyneker, D.G. Yansura, R. Crea, T. Hirose, A. Kraszewski, K. Itakura, A.D. Riggs, Proc. Natl. Acad. Sci. USA 76 (1979) 106-110.

[86] K. Morihara, T. Oka, H. Tsuzuki, Nature 280 (1979) 412-413.

[87] A.S. Rathore, Trends Biotechnol. 27 (2009) 698-705.

[88] M.R. DeFelippis, F.S. Larimore, Biologicals 34 (2006) 49-54

[89] International Conference on Harmonisation, Specifications: Test Procedures and Acceptance Criteria for Biotechnological/Biological Products Q6B, 3-101999, pp. 1-20.

[90] U.S. Department of Health and Human Services - Food and Drug Administration and Center for Drug Evaluation and Research (CDER) Center for Biologics Evaluation and Research (CBER). Guidance for Industry Scientific Considerations in Demonstrating Biosimilarity to a Reference Product - DRAFT GUIDANCE, 2012. <http://www.fda.gov/downloads/Drugs/ GuidanceComplianceRegulatoryInformation/Guidances/UCM291128.pdf>.

[91] U.S. Department of Health and Human Services Food and Drug Administration Center for Drug Evaluation and Research (CDER) Center for Biologics Evaluation and Research (CBER), Guidance for Industry - Quality Considerations in Demonstrating Biosimilarity to a Reference Protein Product - DRAFT GUIDANCE, 2012. <http://www.fda.gov/downloads/Drugs/ GuidanceComplianceRegulatoryInformation/Guidances/UCM291134.pdf> (2-23-2012).

[92] European Medicines Agency - EMEA - Committee for Medicinal Products for Human Use (CHMP), Guideline on Similar Biological Medicinal Products, CHMP/437/04, 10-30-2005, pp. 1-7.

[93] European Medicines Agency - EMEA - Committee for Medical Products for Human Use, Annex Guideline on Similar Biological Medicinal Products Containing Biotechnology-Derived Proteins as Active Substance: Non Clinical and Clinical Issues - Guidance on Similar Medicinal Products Containing Recombinant Human Soluble, Insulin, EMEA/CHMP/BMWP/ 32775/2005, 2-22-2006, pp. 1-6.

[94] D.L. Bakaysa, J. Radziuk, H.A. Havel, M.L. Brader, S. Li, S.W. Dodd, J.M. Beals, A.H. Pekar, D.N. Brems, Protein Sci. 5 (1996) 2521-2531.

[95] S. Zuperl, P. Pristovsek, V. Menart, V. Gaberc-Porekar, M. Novic, J. Chem. Inf. Model. 47 (2007) 737-743.

[96] Y. Aubin, G. Gingras, S. Sauve, Anal. Chem. 80 (2008) 2623-2627.

[97] G. Wagner, S.G. Hyberts, T.F. Havel, Ann. Rev. Biophys. Biomol. Struct. 21 (1992) 167-198.

[98] A.T. Brunger, Nat. Struct. Biol. 4 (Suppl.) (1997) 862-865.

[99] V.A. Silva, M.T. Cargnelutti, G.M. Giesel, L.C. Palmieri, R.Q. Monteiro, H. Verli, L.M. Lima, PLoS ONE 6 (2011) e24735.

[100] K. Wuthrich, Acta Crystallogr. Sec. F. Struct. Biol. Cryst. Commun. 66 (2010) $1365-1366$

[101] K. Carey, Nat. Biotechnol. 29 (2011) 177-178.

[102] H. Ledford, Nature 468 (2010) 18-19.

[103] L.G. Castanheira, D.B. Barbano, N. Rech, Biologicals 39 (2011) 308-311.

[104] A. Mullard, Nat. Rev. Drug Discov. 9 (2010) 905-906.

[105] G. Walsh, Nat. Biotechnol. 28 (2010) 917-924.

[106] L.G. Castanheira, Biologicals 39 (2011) 282-283.

[107] H.N. Kang, Biologicals 39 (2011) 304-307.

[108] C.R. Kowarski, S.S. Lin, L.M. Michalek, A.A. Kowarski, Pharm. Res. 5 (1988) 245-246.

109 C.L. Wu, L.H. Lee, B.R. Lee, C.J. Lee, in: C.L. Wu, L.H. Lee, B.R. Lee, C.J. Lee (Eds.), Clinical Trials of Drugs and Biopharmaceuticals, CRC Taylor \& Francis Group, LLC., Florida, 2006, p. 365.

[110] S.R. Joshi, Biosimilar Insulins: Are they really ‘similar’?, J Assoc. Phys. India 57 (2009) 38-41.

[111] D.A. Hughes, Clin. Pharmacol. Ther. 87 (2010) 257-261.

[112] R.O. iyi-Jones, R.H. Jones, D.G. Barnes, L.S. Gerlis, P.H. Sonksen, Diabetes Care 6 (Suppl. 1) (1983) 9-12.

[113] I.S. Johnson, Diabetes Care 5 (Suppl. 2) (1982) 4-12.

[114] S.E. Fineberg, J.A. Galloway, N.S. Fineberg, M.J. Rathbun, S. Hufferd, Diabetologia 25 (1983) 465-469.

[115] L.M. Keefer, M.A. Piron, M.P. De, Proc. Natl. Acad. Sci. USA 78 (1981) 13911395.

[116] A. Skrlin, I. Radic, M. Vuletic, D. Schwinke, D. Runac, T. Kusalic, I. Paskvan, M. Krsic, M. Bratos, S. Marinc, Biologicals 38 (2010) 557-566.

[117] V. Luzzati, Acta Crystallogr. 5 (1952) 802-810 